\title{
Clinical/serological outcome in humans bitten by Babesia species positive Ixodes ricinus ticks in Sweden and on the Aland Islands
}

Wilhelmsson, P.; Lövmar, M.; Krogfelt, Karen Angeliki; Nielsen, H.V.; Forsberg, Pia; Lindgren, P. E.

Published in:

Ticks and Tick-borne Diseases

DOI:

10.1016/j.ttbdis.2020.101455

Publication date:

2020

Document Version

Peer reviewed version

Citation for published version (APA):

Wilhelmsson, P., Lövmar, M., Krogfelt, K. A., Nielsen, H. V., Forsberg, P., \& Lindgren, P. E. (2020).

Clinical/serological outcome in humans bitten by Babesia species positive Ixodes ricinus ticks in Sweden and on the Åland Islands. Ticks and Tick-borne Diseases, 11(4), [101455]. https://doi.org/10.1016/j.ttbdis.2020.101455

\section{General rights}

Copyright and moral rights for the publications made accessible in the public portal are retained by the authors and/or other copyright owners and it is a condition of accessing publications that users recognise and abide by the legal requirements associated with these rights.

- Users may download and print one copy of any publication from the public portal for the purpose of private study or research.

- You may not further distribute the material or use it for any profit-making activity or commercial gain.

- You may freely distribute the URL identifying the publication in the public portal.

\section{Take down policy}

If you believe that this document breaches copyright please contact rucforsk@kb.dk providing details, and we will remove access to the work immediately and investigate your claim. 


\section{Manuscript Details}

\section{Manuscript number}

Title
TTBDIS_2018_332_R5

Clinical/serological outcome in humans bitten by Babesia species positive Ixodes ricinus ticks in Sweden and on the Åland Islands

\section{Article type}

Research Paper

\section{Abstract}

The risk of contracting babesiosis after a tick bite in Sweden and the Åland Islands, Finland, is unknown. We investigated clinical and serological outcomes in people bitten by Ixodes ricinus ticks positive for Babesia species. Ticks, blood and questionnaires were obtained from study participants in Sweden and on the Åland Islands. Sixty-five of 2098 (3.1\%) ticks were positive by real-time PCR. Three Babesia species were detected, Babesia microti $(n=33), B$. venatorum $(n=27)$ and B. capreoli $(n=5)$, the latter species not known to cause human infection. Half $(46 \%)$ of the Babesia PCR-positive ticks also contained Borrelia spp. Fifty-three participants bitten by a Babesia PCR-positive tick and a control group bitten by a Babesia PCR-negative tick were tested for B. microti IgG antibodies by IFA. The overall seroprevalence was $4.4 \%$, but there was no significant difference between the groups. None of the participants seroconverted and no participant with a Babesia PCR-positive tick sought medical care or reported symptoms suggestive of babesiosis. Given the prevalence of Babesia in I. ricinus ticks in southern Sweden and on the Åland Islands, babesiosis should be considered a possible diagnosis in symptomatic residents who seek medical care following tick exposure.

\section{Keywords}

Corresponding Author

Corresponding Author's Institution

Order of Authors
Babesia; Babesiosis; Human; Seroconversion; Ixodesricinus; Co-infection

\section{Matilda Lövmar}

Linköpings Universitet

Peter Wilhemsson, Matilda Lövmar, Karen Krogfelt, Henrik Vedel Nielsen, Pia Forsberg, Per-Eric Lindgren

\section{Submission Files Included in this PDF}

\section{File Name [File Type]}

Cover letter Ticks and Tick-borne Diseases_180827.docx [Cover Letter]

Response_reviewers_200416.docx [Response to Reviewers]

Additional file 1.docx [Response to Reviewers]

Additional file 2.docx [Response to Reviewers]

Revised_Manuscript_20200416.docx [Manuscript File]

Figure1A.jpg [Figure]

Figure1B.jpg [Figure]

Figure2.jpg [Figure]

Credit Author Statement.docx [Author Statement]

To view all the submission files, including those not included in the PDF, click on the manuscript title on your EVISE Homepage, then click 'Download zip file'. 


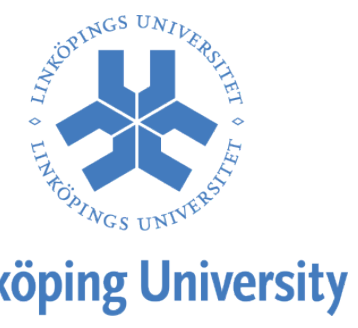

$27^{\text {th }}$ August 2018

Dear Editor,

Please find enclosed a manuscript entitled "Babesia species present in Ixodes ricinus ticks and clinical/serological outcome in humans after an infected tick bite in Sweden and the Åland Islands".

I and my co-authors would be very pleased if you would consider this manuscript for publication as a Research article in the journal Ticks and Tick-borne Diseases.

Babesiosis is a tick-borne human infection in the temperate regions of North America and Eurasia. In many European countries, cases of babesiosis are not mandatorily notifiable by medical practitioners. Therefore, the number of babesiosis cases are unknown. The risk of developing a Babesia infection after a single tick bite is also unknown but depends likely on many factors such as developmental stage of the tick, duration of tick feeding, the Babesia species to be transmitted as well as the number of Babesia parasites in the tick and possible coinfection with other tick-borne pathogens.

In an effort to elucidate the incidence of babesiosis and to investigate how different factors influence the risk of developing a Babesia infection, we collected and analyzed ticks for the presence of Babesia spp. that had been found attached to people in Sweden and Åland Islands (Finland). At the time of the tick bite and three months later, we collected and analyzed blood samples for the presence of anti-Babesia antibodies from the tick-bitten people. In order to determine if participants were diagnosed with babesiosis within the three-month study period, medical records from participants that visited a health care provider were scrutinized. This study involved 1769 tick-bitten participants.

Our results indicate that the risk of contracting babesiosis after a tick bite is low, even if a Babesia-positive tick has been feeding for more than three days and contains up to $10^{7}$ Babesia spp. genome copies per tick. Our findings of participants with positive serology indicate, however, that human infection with Babesia spp. with clinical symptoms occurs in Sweden and in the Åland Islands. Thus, babesiosis should not be neglected as a possible diagnosis in patients experiencing symptoms following a tick bite.

We are convinced that the results of this study should be of great interest to many readers of Ticks and Tick-borne Diseases. We decided to submit this manuscript to Ticks and Tick-borne 


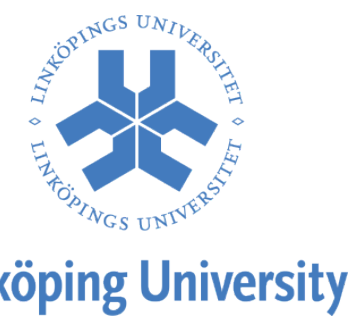

Diseases also because we consider this medical journal to be a highly appreciated scientific journal of excellent quality.

Being the corresponding author, I - and on behalf of all the authors - hereby certify that this paper is an original work. No part of this manuscript has been published previously. All authors have seen and approved the final version of the manuscript.

We very much appreciate your valuable work and look forward to your response.

\author{
Matilda Lövmar, MSc \\ Corresponding author \\ Linköping University \\ Department of Clinical and Experimental Medicine \\ Division of Medical Microbiology \\ SE-581 85 Linköping \\ Sweden
}

Fax: +46(0)10-1034789

E-mail address: matilda.lovmar@liu.se 
Dear Editor,

We would yet again like to thank the reviewers for the valuable comments on our manuscript TTBDIS_2018_332, which have helped us to further substantially improve the quality of the manuscript. We have tried to fulfill all requests and answer all of the questions and give feed-back on the comments raised by the reviewers.

In this letter, point-by-point answers follow. The comments from the reviewers have been copied into this letter and formatted with the Calibri font and put in italics. Our answers follow after each comment in the Times New Roman font.

We hope that this will help with the final decision about the manuscript.

On behalf of all authors,

Matilda Lövmar

Enclosures:

1. The revised manuscript with figures

2. The two questionnaires used in the TBD-STING study, translated into English

\section{Editor and Reviewer Comments:}

- Section editor:

Accept after tidying up the last problems as indicated by reviewer 4 !

\section{-Managing Editor}

The questionable 2 paragraphs can stay in the paper.

Minor comments:

Abstract: Please, write out numbers at the beginning of sentences.

L109-110: These references need some copy editing.

L161 (similar cases also elsewhere in the text): Borrelia-negative

L205: 36 h [space missing]

L226: Twenty-nine

L227 (also elsewhere in the text): No double full stop. 
L339: Nordström

L360-361: Please, use sentence case (no capitalisation of words) rather than title case.

L404: Bergström

L489: Nyström

All of the above mentioned comments have been corrected.

\section{-Reviewer 1}

- All of the issues I had raised were already addressed in the previous revision.

\section{-Reviewer 2}

\section{-Reviewer 3}

\section{-Reviewer 4}

\section{Major Comments}

Line 162: are the 106 controls made of ANY and ALL Babesia and Borrelia negative samples collected during the entire study period, and matched geographically? If not, the seroprevalence, as reported, would be meaningless.

We have changed the text slightly to clarify, see lines 157-160. The controls were chosen from all the Babesia- and Borrelia-negative ticks and geographically matched, twice as many controls were chosen as participants with positive ticks.

Line 212: Figure 2B appears to indicate that the prevalence of $B$. venatorum infected ticks is HIGHER in southcentral Sweden when compared with Aland Islands. Here, the text indicates that the prevalence is HIGHER in the Aland Islands. Which is correct? This comment also applies to the sentence on lines 243-244.

There is no figure $2 \mathrm{~B}$ but we have assumed that the reviewers comment is regarding figure 1B. We have changed the figure text slightly to make this clearer, the statement in the manuscript is correct regarding higher prevalence in the Alland Islands. See the new figure text for Fig 1B.

\section{Minor Comments}

Lines 3-4: the following title "Clinical/serological outcome in humans bitten by Babesia spp. positive Ixodes ricinus ticks in Sweden and on the Aland Islands" may be more attractive to 
the reader, in particular when browsing PubMed.

Thank you for this comment, we have changed the title accordingly.

Lines 36-37: change to "Sixty-five of 2098 ticks were positive (3.1\%) by real-time PCR. Three Babesia species ..."

Changed according to comment.

Line 39: change to "Half (46\%) of the Babesia ...."

Changed according to comment.

Line 39: change to "Fifty-three participants ..."

Changed according to comment.

Lines 44-47: change to "Given the prevalence of Babesia in I. ricinus ticks in southern Sweden and on the Aland Islands, babesiosis should be considered a possible diagnosis in symptomatic residents who seek medical care following tick exposure."

Changed according to comment, we have also altered the conclusion where a similar phrasing was used, see lines 318-322.

Line 53: change to "... transmitted by several tick ..."

Changed according to comment.

Line 55: change to "The first documented case of ..."

Changed according to comment.

Lines 56-57: change to "... was reported in 1957 from Yugoslavia (Skrabalo and Deanovic, 1957). Other cases followed in Western Europe ..."

Changed according to comment.

Line 65: change to "... include fever, malaise, chills, sweats, headache and myalgia ..." Changed according to comment.

Lines 71-73: Add to the citations the report by Moniusko-Malinowska et al. in Infectious Diseases vol 48, pp.537-543, 2016.

This reference has been added to the citations.

Line 81: delete "In Sweden,"

Changed according to comment.

Line 84: delete "However,"

Changed according to comment.

Line 86: delete "previously"

Changed according to comment.

Line 87: modify to "Co-infection with Babesia and Borrelia spp. has been documented ..." Changed according to comment. 
Line 90: delete the number 3, unless it means something.

Deleted according to comment.

Line 92: replace "intensified" with "worse".

Changed according to comment.

Lines 96: delete this part of the sentence "relative to the ..... were used", and use the edited sentence as the last sentence of the previous paragraph.'

We deleted the last part of one sentence according to this comment and moved the sentence to the previous paragraph. The last sentence of the paragraph was moved to the Material and Methods section. See lines 93-101.

Line 104: rephrase as "(PHCS) in the three regions of ..."

Changed according to comment.

Line 114: delete "sera from".

Changed according to comment.

Line 115: delete "serologically".

Changed according to comment.

Line 116: delete "and analyzed for the presence of Babesia spp. using real-time PCR" because the current version of the manuscript no longer includes data on Babesia spp. detected by $P C R$ in human blood samples.

Changed according to comment.

Lines 119-120: rephrase to "In this study, cDNAs from 2098 ticks detached from 1769 participants were analyzed whereas cDNAs from the remaining 12 ticks were not available for analysis."

Changed according to comment.

Lines 123-124: delete ", in total 5 uL cDNA per well."

Changed according to comment.

Line 141: replace "Amplification" with "Extension".

Changed according to comment.

Line 157: rephrase as "... from 53 of the 61 participants bitten by Babesia positive ticks were .."

Changed according to comment.

Line 165: start sentence as "Samples were ...".

Changed according to comment.

Line 182: replace with "Statistical Analysis"

Changed according to comment.

Lines 198-199: delete ", as compared with B. capreoli sequence (AY26009) deposited in Genebank,". This info should be moved to the Methods section. 
We have left some of this information because it is a result from our study and as such should be presented in the results. Because of this comment we have rephrased it slightly, see lines 193-196.

Lines 206-207: move the sentence "Different ticks ...Babesia spp." to after the next sentence. Changed according to comment.

Lines 213-214: rephrase to "No other differences in species composition between regions were significant".

Changed according to comment.

Line 224: rephrase to "Seven participants ...".

Changed according to comment.

Line 252: rephrase to "... in 0.6\% of ticks (Jensen et al. 2017)".

Changed according to comment.

Line 256: change to "...positive larvae among questing ticks, ...".

Changed according to comment.

Line 259: change to "... B. capreoli is known to be ...".

Changed according to comment.

Line 280: delete "on seroprevalence"

Changed according to comment.

Line 282: remove "antibodies".

Changed according to comment. 


\section{To participants of the STING-study}

Please answer all questions!

When did you notice that you had been tick-bitten?

Year-Month-Day:

Time

When do you think you were tick-bitten?

Year-Month-Day:

Time

Where do you think you were when you were tick-bitten? Please state the name of the municipality.

What kind of habitat (vegetation type) had you visited?

Lake/Sea $\square \quad$ Forest $\square \quad$ Garden $\square \quad$ Lawn $\square$

Other:

When was the tick removed?

Year-Month-Day:

Time

Where on the body was the tick attached?

Did you remove the whole tick?

Have you had any other tick bites this season?

If Yes, how many? 1-4 $\square$
Yes $\square \quad$ No $\square \quad$ Do not know $\square$ Yes $\square \quad$ No $\square \quad$ Do not know 
Have you ever been treated for the tick-borne infection Borrelia?

Yes $\square \quad$ No $\square \quad$ Do not know $\square \quad$ If Yes; Year-Month-Day

Did you receive any medicine?

Yes $\square \quad$ No $\square \quad$ Do not know $\square \quad$ If Yes; what kind of medicine did you get?

Have you ever been treated for "Erythema migrans"?

(Erythema migrans = red ring-like or homogenous expanding rash.)

Yes $\square \quad$ No $\square \quad$ Do not know $\square \quad$ If Yes; Year-Month-Day

Did you then receive any medicine to treat the infection?

Yes $\square \quad$ No $\square \quad$ Do not know $\square \quad$ If Yes; what kind?

Have you ever been treated for the tick-borne infection "Ehrlichia" (= Ehrlichiosis, also called "Anaplasma" or anaplasmosis)?

Yes $\square \quad$ No $\square \quad$ Do not know $\square \quad$ If Yes; Year-Month-Day

Did you receive any medicine to cure the Ehrlichia (Anaplasma) infection?

Yes $\square \quad$ No $\square \quad$ Do not know $\square \quad$ If Yes; what kind? 
Have you ever been treated for the tick-borne infection TBE?

( $T B E$ is a viral disease which sometimes causes disease in the central nervous system.)

Yes $\square \quad$ No $\square \quad$ Do not know $\square \quad$ If Yes; Year-Month-Day

Did you receive any medicine?

Yes $\square \quad$ No $\square \quad$ Do not know $\square \quad$ If Yes; what kind?

Do you have any of the following diseases?

Asthma

Allergy

Diabetes

Tumour-related

Are you on medication?

If Yes; what kind of medicine?
Yes $\square \quad$ No $\square \quad$ Do not know $\square$

Yes $\square \quad$ No $\square \quad$ Do not know $\square$

Yes $\square \quad$ No $\square \quad$ Do not know $\square$

Yes $\square \quad$ No $\square \quad$ Do not know $\square$

Yes $\square \quad$ No $\square$

Do you smoke? $\quad$ Yes $\square \quad$ No $\square \quad$ Stopped smoking $\square$ Year

If Yes, how many cigarettes per week?

How many years have you smoked? 
Do you have any pets?

$$
\text { Yes } \square \quad \text { No } \square
$$

Dog

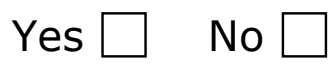

Cat

Yes $\square \quad$ No $\square$

Bunny (rabbit)

Yes $\square \quad$ No $\square$

Other:

Have you been vaccinated against TBE?

Yes $\square \quad$ No $\square \quad$ Do not know

If Yes; Year-Month-Day

Have you been vaccinated against Yellow fever? $\quad$ Yes $\square \quad$ No $\square$ Do not know $\square$ If Yes; Year-Month-Day

Have you been vaccinated against Japanese encephalitis? Yes $\square \quad$ No $\square \quad$ Do not know $\square$ If Yes; Year-Month-Day 


\section{Dear STING participant!}

Three months have passed since you initiated your participation in the Tick-Borne Diseases STING-study. We previously received blood samples from you and a filled in questionnaire. Now, we need a follow-up blood sample. Therefore, you are requested to visit your primary health care centre at week a clock. , Monday, Tuesday, Wednesday, or Thursday, between and

If you had any additional tick-bites since your study initiation and if you have collected the ticks in the tube with yellow cork, the please take that tube with you to the blood-sampling.

We would also like to know if you have had any symptoms related to tick-borne diseases during the study period. Please answer the following three questions and write your name, birth date and telephone number on the next page. We might contact you if you reported symptoms. Take this paper to your primary health care centre when you go for the sample-taking.

\section{1) Have you had any additional tick-bites since the first sample-taking?}

Yes $\square \quad$ No $\square \quad$ Do not know $\square$

If Yes; when? Year-Month-Day:

2) How have you been feeling in general since the first sample-taking? Have you been feeling good/as usual?

Yes $\square \quad$ No $\square \quad$ Do not know $\square$

If No; please report if you had any of the following symptoms:

Headache

Fatigue

Fever, $38^{\circ}$ or higher

Neck pain

Loss of appetite

Nausea

Weight loss

Vertigo

Concentration difficulties

Radiating pain

Muscle or joint pain
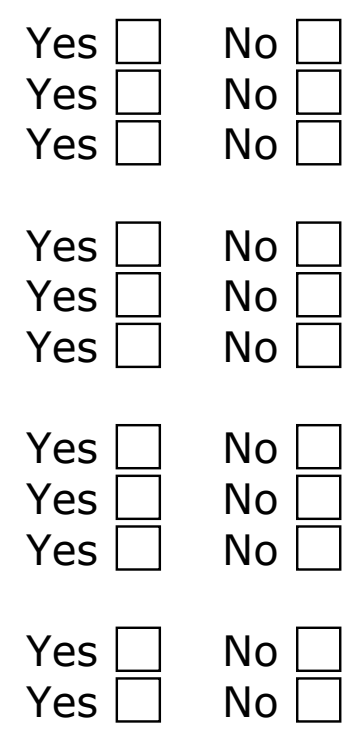
Numbness Yes $\square \quad$ No $\square$

3) If you reported any symptoms in question 2, did the symptoms appear before or after any additional tick-bites?

Before additional tick-bite

Yes $\square \quad$ No $\square \quad$ Do not know $\square$

After additional tick-bite

Yes $\square \quad$ No $\square \quad$ Do not know $\square$

4) If you reported any symptoms in question 2, did you visit your primary health care centre due to the symptoms?

$$
\text { Yes } \square \quad \text { No } \square
$$

5) If you reported any symptoms in question 2, how many days did the symptoms last?

Thanks for your answers!

Please make sure you answered every question!

Bring this paper to your new sample-taking!

Name:

Date of birth:

Telephone number:

Home

Work

Mobile

Best regards

Lotta Lindvall

Forskningssköterska

Infektionskliniken

Universitetssjukhuset

58185 Linköpings

Tfn Xxx/XXX Xxxx 
2020-04-16

\section{TITLE PAGE}

2 Title

3 Clinical/serological outcome in humans bitten by Babesia species positive Ixodes

4 ricinus ticks in Sweden and on the Åland Islands

\section{AUTHORS}

6 Wilhelmsson $\mathrm{P}^{1,2 *}$

7 Lövmar $\mathrm{M}^{1 *}$

$8 \quad$ Krogfelt $\mathrm{KA}^{3,4}$

$9 \quad$ Nielsen $\mathrm{HV}^{3}$

10 Forsberg $\mathrm{P}^{5}$

11 Lindgren $\mathrm{PE}^{1,2}$

$12{ }^{1}$ Division of Medical Microbiology, Department of Biomedical and Clinical Sciences,

13 Linköping University, Linköping, Sweden

14 matilda.lovmar@liu.se

152 Division of Medical Services, Department of Clinical Microbiology, Ryhov County

16 Hospital, Jönköping, Sweden

17 per-eric.lindgren@liu.se

$18{ }^{3}$ Department of Bacteria Parasites and Fungi, Statens Serum Institute, Copenhagen, Denmark

19 kak@ssi.dk, $\underline{\text { hvn@,ssi.dk }}$

$20 \quad{ }^{4}$ Department of Science and Environmental, Roskilde University, Denmark

21 Division of Infectious Diseases, Department of Biomedical and Clinical Sciences, Linköping

22 University, Linköping, Sweden

23 pia.forsberg@liu.se 


8

* these authors contributed equally to this article

*Corresponding author: Matilda Lövmar, Email: matilda.lovmar@liu.se

Linköping University, Department of Biomedical and Clinical Sciences, Division of Medical Microbiology, 58185 Linköping Phone: (+46) 101032054

\section{ABSTRACT}

2 The risk of contracting babesiosis after a tick bite in Sweden and the Åland Islands, Finland,

3 is unknown. We investigated clinical and serological outcomes in people bitten by Ixodes ricinus ticks positive for Babesia species. Ticks, blood and questionnaires were obtained from study participants in Sweden and on the Åland Islands. Sixty-five of 2098 (3.1\%) ticks were positive by real-time PCR. Three Babesia species were detected, Babesia microti $(\mathrm{n}=33)$, B. venatorum $(\mathrm{n}=27)$ and B. capreoli $(\mathrm{n}=5)$, the latter species not known to cause human infection. Half (46\%) of the Babesia PCR-positive ticks also contained Borrelia spp. Fifty-three participants bitten by a Babesia PCR-positive tick and a control group bitten by a Babesia PCR-negative tick were tested for B. microti IgG antibodies by IFA. The overall seroprevalence was $4.4 \%$, but there was no significant difference between the groups. None of the participants seroconverted and no participant with a Babesia PCR-positive tick sought medical care or reported symptoms suggestive of babesiosis. Given the prevalence of Babesia in I. ricinus ticks in southern Sweden and on the Åland Islands, babesiosis should be considered a possible diagnosis in symptomatic residents who seek medical care following tick exposure. 
2020-04-16

$48 \quad$ Keywords

49

50

\section{INTRODUCTION}

52 Human babesiosis is caused by parasites of the genus Babesia and transmitted by several tick 53 species (Vannier and Krause, 2012). There are more than 100 known Babesia spp. that infect 54 animals but only a few are known to infect humans. The first documented case of human 55

Babesia; Babesiosis; Human; Seroconversion; Ixodes ricinus; Co-infection babesiosis in Europe was reported in 1957 from Yugoslavia (Skrabalo and Deanovic, 1957). Other cases followed in Western Europe, including Scandinavia (Haapasalo et al., 2010; Morch et al., 2015) and a travel-associated case in Denmark (Holler et al., 2013). In Sweden there have been two reported cases of human babesiosis, both in splenectomized patients (Bläckberg et al., 2018; Uhnoo et al., 1992). In North America, babesiosis is considered an emerging health threat that is expanding into new geographical areas and may be overlooked by clinicians in regions not previously considered endemic (Gray and Herwaldt, 2019). Most cases in the United States have been reported in immunocompetent patients (Vannier et al., 2015). The first case in the United States was reported in 1966 (Scholtens et al., 1968).

Symptoms of babesiosis include fever, malaise, chills, sweats, headache and myalgia accompanied by anemia, leukopenia or leukocytosis, thrombocytopenia and elevated hepatic enzymes (Vannier and Krause, 2012). In Europe the most common cause of human babesiosis is Babesia divergens, which typically is diagnosed in immunocompromised individuals and gives rise to a severe illness (Vannier et al., 2015; Vannier and Krause, 2012). Infection with $B$. divergens has also been reported in immunocompetent patients (Martinot et al., 2011). A few cases of B. microti and B. venatorum infection have been reported in Europe (Bläckberg et al., 2018; Blum et al., 2011; Haselbarth et al., 2007; Herwaldt et al., 2003; 
72 Hildebrandt et al., 2007; Moniuszko-Malinowska et al., 2016). Infection with B. venatorum, 73 giving mild to severe symptoms in splenectomized patients, has been reported (Haselbarth et al., 2007; Herwaldt et al., 2003). In the United States, B. microti is the most common causative

agent of babesiosis; it causes mild to moderate symptoms and subclinical infections in immunocompetent persons (Vannier et al., 2015; Vannier and Krause, 2012). However, severe babesiosis may also occur, even in previously apparently healthy individuals (Gray and Herwaldt, 2019; Hatcher et al., 2001).

In Sweden, the prevalence of Babesia spp. in questing I. ricinus ticks was recently estimated to be $4.4 \%$ and included $B$. microti $(3.2 \%)$, B. venatorum $(1.0 \%)$ and $B$. divergens (0.2\%) (Karlsson and Andersson, 2015). B. capreoli has been reported in roe deer, but this Babesia sp. is not known to cause human infections (Andersson et al., 2016; Malandrin et al., 2010). In Italy, the prevalence of $B$. venatorum in ticks that have bitten humans was estimated to be $0.6 \%$ (Otranto et al., 2014). To our knowledge, the clinical outcome and the rate of seroconversion after a bite by a Babesia containing tick or a tick coinfected with Borrelia, have not been investigated.

Co-infection with Babesia and Borrelia spp. has been documented several times (Diuk-Wasser et al., 2016; Knapp and Rice., 2015). There are differing opinions on the consequences of co-infection for severity of symptoms and prognosis in humans. According to Diuk-Wasser et al., (2016), the severity and duration of symptoms are greater in coinfected patients and there are indications that co-infection may result in altered or suppressed immune response, which in turn leads to worse pathogenesis; more research is, however, needed. The aims of the present study were to investigate the prevalence of Babesia spp. in ticks that had bitten humans and to evaluate the concomitant risk of clinical babesiosis or subclinical seroconversion against Babesia spp. 
2020-04-16

MATERIAL AND METHODS

97

\section{TBD STING-study}

Ticks, serum and questionnaires from the Tick-Borne Diseases (TBD) STING-study were used (Fryland et al., 2011; Grankvist et al., 2015; Henningsson et al., 2015; Henningsson et al., 2016; Lindblom et al., 2014; Wilhelmsson et al., 2010; Wilhelmsson et al., 2013a; Wilhelmsson et al., 2013b).

Ticks and blood samples were collected during 2008-2009 at 34 primary healthcare centers (PHCs) in the three regions of Sweden (Northern Sweden, South Central Sweden and Southernmost Sweden) and on the Åland Islands, Finland (Figure 1A). Only immunocompetent tick-bitten individuals $\geq 18$ years were included. Questionnaires, ethical approval, collection, transport and storage of ticks and blood samples, determination of developmental stage and feeding time of ticks, and extraction and treatment of nucleic acids have been described previously (Andersson et al., 2016; Wilhelmsson et al., 2013a; Wilhelmsson et al., 2013b). Babesia spp. were detected using real-time PCR-based amplification of reverse-transcribed total nucleic acids.

Blood samples were collected from participants within three days of the tick bite and three months later (Figure 2). Serum samples from participants with Babesia PCRpositive ticks and a negative control group, consisting of participants bitten by a Babesia PCR-negative tick, geographically matched, were analyzed by IFA.

\section{Detection of Babesia spp. in ticks using SYBR-green real-time PCR assay}

A total of 2110 ticks detached from 1770 participants were delivered from PHCs during 2008-2009. In this study, cDNAs from 2098 ticks detached from 1769 participants were analyzed whereas cDNAs from the remaining 12 ticks were not available for analysis. 
The 2098 cDNA samples of the individually extracted ticks were grouped into pools of five, i.e. one $\mu \mathrm{l}$ of cDNA from each tick was used per well. Samples from the positive pools were individually analyzed using $2 \mu \mathrm{cDNA}$. The PCR mixture contained 10 $\mu$ l SYBR-green (Thermo Scientific, Helsingborg, Sweden), $0.4 \mu \mathrm{l}$ of each primer $(10 \mu \mathrm{M})$, BJ1: 5'-GTC TTG TAA TTG GAA TGA TGG-3' (Invitrogen ${ }^{\mathrm{TM}}$, Thermo Scientific) and BN2: 5'-TAG TTT ATG GTT AGG ACT ACG-3' (Casati et al., 2006), $4.2 \mu 1$ RNase free water. Primers BJ1 and BN2 were designed to target the Babesia $18 S$ rRNA gene to amplify a 411 to 452 bp long amplicon depending on the species of Babesia. For species determination, sequencing of the amplicon was carried out (see below). As a positive control, $2 \mu \mathrm{l}$ B. microti DNA ( $10 \mathrm{ng} / \mu \mathrm{l})$, extracted from I. ricinus ticks collected in Slovakia (kindly provided by Dr Bronislava Víchová, through Dr Martin Andersson), and $2 \mu 1$ of a synthetic plasmid preparation was used. The plasmid contained the target sequence of the SYBR green real-time PCR assay, spanning the nucleotides 467-955 of the $B$. divergens $18 S$ rRNA gene (acc. no AJ439713), synthesized and cloned in a pUC57 vector (Genscript USA Inc, NJ). The non-template control consisted of $10.8 \mu 1$ PCR mixture and $9.2 \mu 1$ RNase free water. The SYBR-green real-time PCR on Babesia were performed using C1000 ${ }^{\mathrm{TM}}$ Thermal Cycler, CFX96 ${ }^{\mathrm{TM}}$ system (BioRad Laboratories, Inc., Hercules, CA). The PCR run was initiated by a denaturation step at $94^{\circ} \mathrm{C}$ for 10 min followed by 35 cycles of denaturation at $94^{\circ} \mathrm{C}$ for $1 \mathrm{~min}$, annealing at $55^{\circ} \mathrm{C}$ for $1 \mathrm{~min}$ and elongation at $72^{\circ} \mathrm{C}$ for $2 \mathrm{~min}$. Extension was completed by a further step at $72^{\circ} \mathrm{C}$ for $5 \mathrm{~min}$, and melt curve analysis was performed (Casati et al., 2006). 
version 7.2.5 (Tom Hall, Ibis Therapeutics, Carlsbad, CA) and sequences examined using the

Basic Local Alignment Tool (BLAST). Sequences obtained have been deposited in GenBank with accession numbers ranging from MH351680 to MH351744.

147 Species determination for $B$. microti and $B$. venatorum is possible by sequencing the amplicon from the real-time PCR assay. To fully distinguish between the two genetically similar Babesia spp., B. divergens and B. capreoli, three sets of primers were used to amplify and sequence the complete $18 S$ rRNA gene from all samples positive for these species, as earlier described (Malandrin et al., 2010).

\section{Detection of Babesia microti IgG antibodies in human serum}

The first and second serum samples (collected at recruitment of participants and three months later, respectively) from 53 of the 61 participants bitten by Babesia-positive ticks were analyzed for the presence of $B$. microti $\mathrm{IgG}$ antibodies, using an indirect immunofluorescence assay (IFA); (Focus Diagnostics, Cypress, CA). For the remaining eight participants, serum was not available for analysis, since it had been used for other analyses. Twice as many controls were selected; first sample sera from participants bitten by Babesia- and Borrelianegative ticks were matched geographically and used as controls $(n=106)$ for analysis regarding IgG antibodies against $B$. microti. For $B$. venatorum there were no commercial kits available at the time of the study. IFA titers $\geq 1: 64$ were defined as positive. A cut-off value of 1:64 was used in accordance with previous research (Johnson et al., 2009). Samples were diluted to determine the highest positive titer. The IFA-slides were analyzed by two researchers independently, samples were defined as positive when both researchers found them positive. For the diagnosis of on-going or recent Babesia spp. infection, at least a fourfold rise of the IFA titer (Krause, 2003; Vannier and Krause, 2012) was required when first and second sera were tested simultaneously. 
Self-reported symptoms in the questionnaires of the TBD STING-study and medical records

The questionnaires from participants with Babesia PCR-positive ticks were scrutinized for symptoms suggestive of babesiosis, i.e. chills, fever, headache, nausea, myalgia, malaise, weight loss, arthralgia and lack of appetite (Vannier and Krause, 2012). Other symptoms indicating TBD in the questionnaires were neck pain, vertigo, concentration difficulties, numbness, radiating pain. If participants sought medical care during the three-month study

175 period, the medical records were obtained and scrutinized for symptoms of babesiosis and/or 176 if they were diagnosed with babesiosis or another TBD.

\section{Co-infection of tick-borne pathogens in ticks}

178 Borrelia-data from the TBD STING-study were used to determine which ticks were co179 infected with both Babesia spp. and Borrelia spp. (Wilhelmsson et al., 2013a).

\section{Statistical analysis}

181 The Chi square test was applied to compare prevalence of Babesia spp. between regions and between tick developmental stages, but when the expected frequency was $<5$ in at least one of the cells of the contingency table, we used Fisher's exact test. Statistical analyses were performed using GraphPad Prism version 6.04 for Windows (GraphPad Software, San Diego, CA). P-values $<0.05$ were considered significant.

\section{RESULTS}

\section{Babesia species in ticks detached from humans}

188 A total of 2098 ticks that had bitten humans were analyzed (Table 1). Sixty (2.9\%) of the 189 ticks were damaged to the extent that neither developmental stage nor the species could be 190 determined. The remaining 2038 ticks were identified as I. ricinus; 86 (4.1\%) larvae, 1466 
191 (70\%) nymphs, and $486(23 \%)$ adults. 65 of 2098 ticks (3.1\%) were positive for Babesia spp.

\section{Co-infection with Babesia spp. and Borrelia spp. in ticks}

212 To find which ticks contained Borrelia spp., data from the TBD STING-study were used

213 (Wilhelmsson et al., 2013a). Thirty out of 65 (46\%) Babesia spp. positive ticks contained

by real-time PCR assay. Based on nucleotide sequencing of the PCR products, three Babesia species were detected; $B$. microti $(\mathrm{n}=33)$, B. venatorum $(\mathrm{n}=27)$, and B. capreoli $(\mathrm{n}=5)$. Our analysis of the complete $18 \mathrm{~S}$ rDNA sequences for the five samples initially determined as either B. divergens or B. capreoli revealed a signature typical of B. capreoli at positions 631, 663 and 1637 (GTT), as compared with B. capreoli sequence (GeneBank: AY26009). In our study there was no significant difference in Babesia prevalence between adult ticks and nymphs or between nymphs and larvae. However, the prevalence of $B$. microti was significantly higher in adult ticks than in nymphs $(\mathrm{p}<0.05)$.

The 65 PCR-positive ticks were collected from 61 participants and the duration of tick feeding could be estimated for 58 of the 65 ticks (Appendix). 21 of these ticks had been feeding for $>36 \mathrm{~h}$ and the remaining 37 ticks $<36 \mathrm{~h}$. There were three participants bitten by more than one infected tick. One participant from the Åland Islands was bitten by three infected ticks, one from Southcentral Sweden was bitten by two infected ticks, and one from Southernmost Sweden was bitten by two infected ticks (Appendix). Different ticks from the same participant contained different Babesia spp. There was no significant difference in prevalence of infected ticks between the geographic regions (Figure 1B). However, there was a significant difference in species composition of Babesia between the geographic regions, with $B$. venatorum more prevalent in the Åland Islands than in Southcentral Sweden $(\mathrm{p}<0.03)$. No other differences in species composition between the regions were significant. Borrelia spp. (Appendix). There was a significant difference in the frequency of co-infections 
involving B. microti and Borrelia spp. (60\%) and the frequency of co-infections involving $B$. venatorum and Borrelia spp. $(30 \%)(\mathrm{p}<0.01)$.

\section{Seroprevalence, seroconversion and reported symptoms of the tick-bitten participants}

218 The overall seroprevalence for B. microti was 7 out of $159(4.4 \%)$ with no significant

Twenty-nine participants were bitten by ticks containing both Babesia spp. and Borrelia spp. One of these participants was bitten by two ticks positive for Babesia spp. and Borrelia spp. Data regarding seroconversion for Borrelia spp. showed that one of the participants who seroconverted to Borrelia had a Babesia PCR-positive tick. However, this participant had a negative B. microti serology.

There were ten participants with Babesia PCR-positive ticks who reported symptoms in their questionnaires. The symptoms included headache, muscle pain, fatigue, neck pain, dizziness, concentration difficulties, numbness, radiating pain, joint pain and nausea. Only one of these participants had B. microti IgG antibodies. This participant sought medical care at the PHC during the study period but according to notes found in the medical records, symptoms were deemed not relevant to the tick bite.

\section{DISCUSSION}

To our knowledge this is the first time Babesia has been found in ticks that have bitten humans in Sweden. In total, 3.1\% of ticks collected from four regions in Sweden and in the Åland Islands contained Babesia spp. Babesia infected ticks were found in three of the four regions studied (Fig. 1B). A previous study on the prevalence of Babesia spp., in questing ticks in southern Sweden, found a prevalence of $4.4 \%$ which is in line with our findings 
(Karlsson and Andersson, 2015). Comparing prevalence of Babesia spp. in the different regions, B. venatorum was more prevalent on the Åland Islands than in Southcentral Sweden.

One could speculate the difference is related to different Babesia reservoir host composition.

243 humans was B. microti, followed by B. venatorum and B. capreoli. In Sweden B. capreoli has been found in $44 \%$ of roe deer (Andersson et al., 2016), but this species is not known to cause

We found that the most prevalent species in ticks collected from human infections (Malandrin et al., 2010). We did not find any samples positive for $B$.

divergens. A study conducted in Norway found that $0.1 \%$ of field-collected ticks are infected with $B$. divergens, $0.1 \%$ with $B$. capreoli and $0.6 \%$ with $B$. venatorum (Øines et al., 2012). In Denmark, $B$. divergens was found in $1.9 \%$ of ticks and B. venatorum in $0.6 \%$ of ticks (Jensen et al., 2017). Karlsson and Andersson (2015) found 0.2\% questing ticks containing $B$. divergens in Sweden and found no significant difference in prevalence of Babesia spp. in adult ticks compared to nymphs. They found a higher prevalence in nymphs than in adults and they found no positive larvae among questing ticks, but we analyzed four times as many ticks and they were collected from humans. We found only one positive larva (Table 1) that contained B. capreoli. B. capreoli has not previously been found in larvae, however, $B$. divergens which is genetically similar to $B$. capreoli is known to be transovarially transmitted (Bonnet et al., 2007).

Nearly one-half of the ticks positive for Babesia spp. were positive for Borrelia spp. Sixty percent of ticks containing B. microti were co-infected with Borrelia spp. compared to $30 \%$ of ticks containing B. venatorum. This may reflect the genus ratio of Babesia spp. and Borrelia spp. in reservoir hosts. It has been observed in an experimental model that mice co-infected with a strain of $B$. microti and an invasive strain of $B$. burgdorferi s.s. increased B. microti frequency in I. scapularis that fed from them compared 
to mice infected with B. microti alone (Dunn et al., 2014). It remains to be confirmed if this

264 finding applies to I. ricinus and one or several Babesia spp. it can transmit. none of them seroconverted and the antibody titers were low, we did not suspect an ongoing infection (Vannier and Krause, 2012). It is probable that they had a previous or subclinical infection and still carried antibodies. In a previous study, Lempereur et al. (2015) found no antibody cross-reactivity between $B$. microti and $B$. venatorum used as IFA antigens, but IgM cross reactivity between $B$. microti and $B$. divergens has been observed in another study (Haselbarth et al., 2007). Bläckberg et al. (2018) reported that a patient with B. venatoruminfection had $B$. divergens $\operatorname{IgG}$ antibodies. For the participants with a positive $B$. microti serology, only three had been bitten by Babesia PCR-positive ticks during the study period. Because they had the same antibody titers in the first serum sample as in the second, it is not likely that the tick-bite during the study period was the cause of the positive serology or that the participants had an ongoing infection. One study in southern Sweden has revealed a prevalence of $16.3 \%$ for $B$. microti and $B$. divergens antibodies in a geographically selected cohort of seropositive Borrelia s.1. patients; and a $2.5 \%$ prevalence in a healthy control group (Svensson et al., 2019). However, comparing this study to ours is complicated, since we have used another serological assay for Babesia antibodies and the study populations differ from each other.

In total, three participants were bitten by more than one Babesia PCR-positive tick, none of them developed antibodies against $B$. microti during the study period. One of these participants was bitten by ticks containing $B$. capreoli, not confirmed to be human pathogenic. Since we only analyzed for $B$. microti $\operatorname{IgG}$ we cannot draw any general conclusions regarding Babesia spp. antibodies. However, it is an interesting future prospective. None of the participants with more than one positive tick reported symptoms in 
288 their questionnaires or sought medical care during the study period. This suggests a low risk

289 of transmission despite being bitten by several positive ticks and different species.

290 Furthermore, the efficacy of transmission has been shown to correlate with the duration of

291 tick feeding (for I. scapularis) in hamsters and white-footed mice, with infection rates close 292 to $100 \%$ if the tick is allowed to feed to repletion (Piesman and Spielman, 1980). However, it 293 is not known if this is true for I. ricinus and/or human hosts. In our study ticks were removed 294 by the participant before repletion.

Ten participants with Babesia PCR-positive ticks reported symptoms in their

296

297

298

299

300

301

302

303

304

305

306

307

308

309

310

311

312

questionnaires. These symptoms were nonspecific and might indicate different conditions, babesiosis included. Only one participant bitten by a Babesia PCR-positive tick sought medical care during the study period. According to medical records, symptoms were unrelated to the tick bite. Thus, we conclude that none of the participants suffered from symptoms of babesiosis.

Twenty-nine of 61 participants with Babesia PCR-positive ticks were bitten by ticks co-infected with Borrelia. Of the ten participants who reported symptoms, five had been bitten by ticks positive for both Babesia spp. and Borrelia spp. The symptoms reported could be attributed either to babesiosis, borreliosis or other infections. None of the participants who reported symptoms, with the exception of the participant mentioned above, had sought medical care. This suggests that no participant suffered from severe illness.

One of the potential limitations of this study is that we did not test the serum for $B$. venatorum antibodies since we did not have available commercial kits for these analyses. The conclusions that can be drawn from the serological analyses are further limited by the lack of information regarding travel history, since this was not included in the questionnaires, designed for the TBD STING-study. Unfortunately, whole blood samples from the TBD STING-study were not available for real-time PCR analysis. 


\section{Conclusions}

314 In conclusion our results indicate that immunocompetent individuals have a low risk of

315 developing severe babesiosis after an I. ricinus tick bite in Sweden and on the Åland Islands, 316 particularly when the tick has been feeding for less than 36 hours. Our findings of

317 participants with positive serology suggests that human infection with $B$. microti occurs in 318 Sweden, although we do not know about the travel history of these participants. Given the 319 prevalence of Babesia in I. ricinus ticks as well as the seroprevalence of Babesia antibodies 320 among residents in southern Sweden and on the Åland Islands, babesiosis should be 321 considered a possible diagnosis in symptomatic residents who seek medical care following tick exposure. Culture Foundation.

\section{ACKNOWLEDGEMENTS}

The authors would like to thank all participants of the study, as well as the staff at the PHCs participating in the TBD STING study. We would like to thank the members of the TBD STING study group for all the valuable work and advice on the study design and collection logistics. We would also like to thank Dr Andrew Jenkins, Telemark University College, Norway, for excellent linguistic revision. This study was supported by The Swedish Research Council (Branch of Medicine, no. K2008-58X-14631-06-3), The Medical Research Council of Southeast Sweden (FORSS, 657881), Region Östergötland, the Interreg IVA Programme ScandTick, Interreg V ÖKS programme ScandTick Innovation, the Wilhelm and Else Stockmann Foundation, and the Foundation for Åland Medical Research of the Åland 
Andersson, M.O., Bergvall, U.A., Chirico, J., Christensson, M., Lindgren, P.E., Nordström, J., Kjellander, P. 2016. Molecular detection of Babesia capreoli and Babesia venatorum in wild Swedish roe deer, Capreolus capreolus. Parasit. Vectors. 9, 221. https://doi.org/10.1186/s130710161503-8.

Blum, S., Gattringer, R., Haschke, E., Walochnik, J., Tschurtschenthaler, G., Lang, F., Oberbauer, R. 2011. The case: hemlysis and acute renal failure. Babesiosis. Kidney Int. 80, 681-83. https://doi.org/10.1038/ki.2011.184.

Bläckberg, J., Lazarevic, V.L., Hunfeld, K.P., Persson, K.E.M. 2018. Low-virulent Babesia venatorum infection masquerading as hemophagocytic syndrome. Ann. Hematol. 97, 731-733. https://doi.org/10.1007/s00277-017-3220-6.

Bonnet, S., Jouglin, M., Malandrin, L., Becker, C., Agoulon, A., L'Hostis, M., Chauvin, A. 2007. Transstadial and transovarial persistence of Babesia divergens DNA in Ixodes ricinus ticks fed on infected blood in a new skin-feeding technique. Parasitology. 134, 197-207. https://doi.org/10.1017/S0031182006001545

Casati, S., Sager, H., Gern, L., Piffaretti, J.C. 2006. Presence of potentially pathogenic Babesia sp. for human in Ixodes ricinus in Switzerland. Ann Agric Environ Med. 13, 65-70.

Diuk-Wasser, M.A., Vannier, E., Krause, P.J. 2016. Coinfection by Ixodes tick-borne pathogens: ecological, epidemiological, and clinical consequences. Trends Parasitol. 32, 30-42. https://doi.org/10.1016/j.pt.2015.09.008

Dunn, J.M., Krause, P.J., Davis, S., Vannier, E.G., Fitzpatrick, M.C., Rollend, L., Belperron, A.A., States, S.L., Stacey, A., Bockenstedt, L.K., Fish, D., Diuk-Wasser, M.A. 2014. Borrelia burgdorferi promotes the establishment of Babesia microti in the northeastern United States. PLoS One. 9, e115494. https://doi.org/10.1371/journal.pone.0115494

Fryland, L., Wilhelmsson, P., Lindgren, P.E., Nyman, D., Ekerfelt, C., Forsberg, P. 2011. Low risk of developing Borrelia burgdorferi infection in the south-east of Sweden after being bitten by a Borrelia burgdorferi-infected tick. Int J Infect Dis. 15, e174-81. https://doi.org/10.1016/j.ijid.2010.10.006

Grankvist, A., Sandelin, L.L., Andersson, J., Fryland, L., Wilhelmsson, P., Lindgren, P.E., Forsberg, P., Wenneras, C. 2015. Infections with Candidatus Neoehrlichia mikurensis and cytokine responses in 2 persons bitten by ticks, Sweden. Emerg Infect Dis. 21, 1462-65. https://doi.org/ 10.3201/eid2108.150060

Gray, E.B., Herwaldt, B.L. 2019. Babesiosis Surveillance - United States, 2011-2015. MMWR Surveill Summ. 68, 1-11. https://doi.org/10.15585/mmwr.ss6806a1.

Gray, J., Stanek, G., Kundi, M., Kocianova, E. 2005. Dimensions of engorging Ixodes ricinus as a measure of feeding duration. Int J Med Microbiol. 295, 567-72. 
Haapasalo, K., Suomalainen, P., Sukura, A., Siikamaki, H., Jokiranta, T.S. 2010. Fatal babesiosis in man, Finland, 2004. Emerg Infect Dis. 16, 1116-18.

https://doi.org/10.3201/eid1607.091905

Haselbarth, K., Tenter, A.M., Brade, V., Krieger, G., Hunfeld, K.P. 2007. First case of human babesiosis in Germany - clinical presentation and molecular characterisation of the pathogen. Int J Med Microbiol. 297, 197-204.

https://doi.org/10.1016/j.ijmm.2007.01.002

Hatcher, J.C., Greenberg, P.D., Antique, J., Jimenez-Lucho, V.E. 2001. Severe babesiosis in Long Island: review of 34 cases and their complications. Clin Infect Dis. 32, 1117-25. https://doi.org/10.1086/319742

Henningsson, A.J., Wilhelmsson, P., Gyllemark, P., Kozak, M., Matussek, A., Nyman, D., Ekerfelt, C., Lindgren, P.E., Forsberg, P. 2015. Low risk of seroconversion or clinical disease in humans after a bite by an Anaplasma phagocytophilum-infected tick. Ticks Tick Borne Dis. 6, 787-92. https://doi.org/10.1016/j.ttbdis.2015.07.005

Henningsson, A.J., Lindqvist, R., Norberg, P., Lindblom, P., Roth, A., Forsberg, P., Bergström, T., Överby, A.K., Lindgren, P.E. 2016. Human tick-borne encephalitis and characterization of virus from biting tick. Emerg Infect Dis. 22, 1485-87. https://doi.org/10.3201/eid2208.151962

Herwaldt, B.L., Caccio, S., Gherlinzoni, F., Aspock, H., Slemenda, S.B., Piccaluga, P., Martinelli, G., Edelhofer, R., Hollenstein, U., Poletti, G., Pampiglione, S., Loschenberger, K., Tura, S., Pieniazek, N.J. 2003. Molecular characterization of a non-Babesia divergens organism causing zoonotic babesiosis in Europe. Emerg Infect Dis. 9, 942-48. https://doi.org/10.3201/eid0908.020748

Hildebrandt, A., Hunfeld, K.P., Baier, M., Krumbholz, A., Sachse, S., Lorenzen, T., Kiehntopf, M., Fricke, H.J., Straube, E. 2007. First confirmed autochthonous case of human Babesia microti infection in Europe. Eur J Clin Microbiol Infect Dis. 26, 595-601. https://doi.org/10.1007/s10096-007-0333-1

Holler, J.G., Roser, D., Nielsen, H.V., Eickhardt, S., Chen, M., Lester, A., Bang, D., Frandsen, C., David, K.P. 2013. A case of human babesiosis in Denmark. Travel Med Infect Dis. 11, 324-28. https://doi.org/10.1016/j.tmaid.2013.06.003

Jensen, P.M., Christoffersen, C.S., Moutailler, S., Michelet, L., Klitgaard, K., Bodker, R. 2017. Transmission differentials for multiple pathogens as inferred from their prevalence in larva, nymph and adult of Ixodes ricinus (Acari: Ixodidae). Exp Appl Acarol. 71, 171-182. 
Johnson, S.T., Cable, R.G., Tonnetti, L., Spencer, B., Rios, J., Leiby, D.A. 2009. Seroprevalence of Babesia microti in blood donors from Babesia-endemic areas of the northeastern United States: 2000 through 2007. Transfusion. 49, 2574-82.

https://doi.org/10.1111/j.1537-2995.2009.02430.x

Karlsson, M.E., Andersson, M.O. 2015. Babesia species in questing Ixodes ricinus, Sweden. Ticks Tick Borne Dis. 7, 10-12.

https://doi.org/10.1016/j.ttbdis.2015.07.016

Knapp, K.L., Rice, N.A. 2015. Human coinfection with Borrelia burgdorferi and Babesia microti in the United States. J Parasitol Res. 2015, 587131. https://doi.org/10.1155/2015/587131

Krause, P.J. 2003. Babesiosis diagnosis and treatment. Vector Borne Zoonotic Dis. 3, 45-51. https://doi.org/10.1089/153036603765627451

Lempereur, L., Shiels, B., Heyman, P., Moreau, E., Saegerman, C., Losson, B., Malandrin, L. 2015. A retrospective serological survey on human babesiosis in Belgium. Clin Microbiol Infect. 21, 96.e1-7. https://doi.org/10.1016/j.cmi.2014.07.004

Lindblom, P., Wilhelmsson, P., Fryland, L., Sjowall, J., Haglund, M., Matussek, A., Haglund, M., Sjowall, J., Vene, S., Nyman, D., Forsberg, P., Lindgren, P.E. 2014. Tick-borne encephalitis virus in ticks detached from humans and follow-up of serological and clinical response. Ticks Tick Borne Dis. 5, 21-28. https://doi.org/10.1016/j.ttbdis.2013.07.009

Malandrin, L., Jouglin, M., Sun, Y., Brisseau, N., Chauvin, A. 2010. Redescription of Babesia capreoli (Enigk and Friedhoff, 1962) from roe deer (Capreolus capreolus): isolation, cultivation, host specificity, molecular characterisation and differentiation from Babesia divergens. Int J Parasitol. 40, 277-84. https://doi.org/10.1016/j.ijpara.2009.08.008

Martinot, M., Zadeh, M.M., Hansmann, Y., Grawey, I., Christmann, D., Aguillon, S., Jouglin, M., Chauvin, A., De Briel, D. 2011. Babesiosis in immunocompetent patients, Europe. Emerg Infect Dis. 17, 114-16. https://doi.org/10.3201/eid1701.100737

Moniuszko-Malinowska, A., Swiecicka, I., Dunaj, J., Zajkowska, J., Czupryna, P., Zambrowski, G., Chmielewska-Badora, J., Żukiewicz-Sobczak, W., Swierzbinska, R., Rutkowski, K., Garkowski, A., Pancewicz, S. 2016. Infection with Babesia microti in humans with non-specific symptoms in North East Poland. Infect Dis (Lond). 48, 537-43. https://doi.org/10.3109/23744235.2016

Mørch, K., Holmaas, G., Frolander, P.S., Kristoffersen, E.K. 2015. Severe human Babesia divergens infection in Norway. Int J Infect Dis. 33, 37-38. https://doi.org/10.1016/j.ijid.2014.12.034

Øines, Ø., Radzijevskaja, J., Paulauskas, A., Rosef, O. 2012 Prevalence and diversity of Babesia spp. in questing Ixodes ricinus ticks from Norway. Parasit Vectors. 5, 156. 
Otranto, D., Dantas-Torres, F., Giannelli, A., Latrofa, M.S., Cascio, A., Cazzin, S., Ravagnan, S., Montarsi, F., Zanzani, S.A., Manfredi, M.T., Capelli, G. 2014. Ticks infesting humans in Italy and associated pathogens. Parasit Vectors. 7, 328.

https://doi.org/10.1186/1756-3305-7-328

Piesman, J., Spielman, A. Human babesiosis on Nantucket Island: prevalence of Babesia microti in ticks. 1980. Am J Trop Med Hyg. 29, 742-46. https://doi.org/10.4269/ajtmh.1980.29.742

Scholtens, R.G., Braff, E.H., Healey, G.A., Gleason, N. 1968. A case of babesiosis in man in the United States. Am J Trop Med Hyg. 17, 810-13. https://doi.org/10.4269/ajtmh.1968.17.810

Skrabalo, Z., Deanovic, Z. 1957. Piroplasmosis in man; report of a case. Doc Med Geogr Trop. 9, 1116.

Svensson, J., Hunfeld, K.P., Persson, K.E.M. 2019. High seroprevalence of Babesia antibodies among Borrelia burgdorferi-infected humans in Sweden. Ticks Tick Borne Dis. 10, 186-190.

https://doi.org/10.1016/j.ttbdis.2018.10.007

Uhnoo, I., Cars, O., Christensson, D., Nyström-Rosander, C. 1992. First documented case of human babesiosis in Sweden. Scand J Infect Dis. 24, 541-47.

https://doi.org/10.3109/00365549209052642

Vannier, E., Krause, P.J. 2012. Human babesiosis. N Engl J Med. 366, 2397-407. https://doi.org/10.1056/NEJMra1202018

Vannier, E.G., Diuk-Wasser, M.A., Ben Mamoun, C., Krause, P.J. 2015. Babesiosis. Infect Dis Clin North Am. 29, 357-70. https://doi.org/10.1016/j.idc.2015.02.008

Wilhelmsson, P., Fryland, L., Borjesson, S., Nordgren, J., Bergström, S., Ernerudh, J., Forsberg, P., Lindgren, P.E. 2010. Prevalence and diversity of Borrelia species in ticks that have bitten humans in Sweden. J Clin Microbiol. 48, 4169-76.

https://doi.org/10.1128/JCM.01061-10

Wilhelmsson, P., Lindblom, P., Fryland, L., Ernerudh, J., Forsberg, P., Lindgren, P.E. 2013a. Prevalence, diversity, and load of Borrelia species in ticks that have fed on humans in regions of Sweden and Aland Islands, Finland with different Lyme borreliosis incidences. PLoS One. 8, e81433. https://doi.org/10.1371/journal.pone.0081433

Wilhelmsson, P., Lindblom, P., Fryland, L., Nyman, D., Jaenson, T. G., Forsberg, P., Lindgren, P. E. 2013b. Ixodes ricinus ticks removed from humans in Northern Europe: seasonal pattern of 
infestation, attachment sites and duration of feeding. Parasit Vectors. 6, 362.

516

517 Table 1. Analyzed ticks and distribution of developmental stages.

\begin{tabular}{|c|c|c|c|c|c|}
\hline $\begin{array}{l}\text { Developmental } \\
\text { stage of the tick }\end{array}$ & $\begin{array}{l}\text { Total no. of } \\
\text { ticks analyzed }\end{array}$ & $\begin{array}{l}\text { No. of Babesia } \\
\text { PCR-positive } \\
\text { ticks (\%) }\end{array}$ & $\begin{array}{l}\text { No. of ticks PCR- } \\
\text { positive for } B \text {. } \\
\text { microti }\end{array}$ & $\begin{array}{l}\text { No. of ticks PCR- } \\
\text { positive for } B \text {. } \\
\text { venatorum }\end{array}$ & $\begin{array}{l}\text { No. of ticks PCR- } \\
\text { positive for } B \text {. } \\
\text { capreoli }\end{array}$ \\
\hline Adult females & 478 & $20(4.2)$ & 13 & 6 & 1 \\
\hline Adult males & 8 & $1(12.5)$ & 0 & 1 & 0 \\
\hline Nymphs & 1466 & $43(2.9)$ & 20 & 20 & 3 \\
\hline Larvae & 86 & $1(1.2)$ & 0 & 0 & 1 \\
\hline $\mathrm{ND}^{*}$ & 60 & $0(0)$ & 0 & 0 & 0 \\
\hline Total & 2098 & $65(3.1)$ & 33 & 27 & 5 \\
\hline
\end{tabular}

518 *Developmental stage could not be determined due to damaged tick

519

520

Table 2. B. microti lgG antibody titers for samples positive in the serological analysis $(n=7)$.

\begin{tabular}{|c|c|c|c|c|c|}
\hline $\begin{array}{l}\text { Participant } \\
\text { Id. code." }\end{array}$ & $\begin{array}{l}\text { Antibody titers in } \\
\text { 1st }^{\text {st }} \text { sample }^{\ddagger}\end{array}$ & $\begin{array}{l}\text { Antibody titers in } \\
2^{\text {nd }} \text { sample }{ }^{\ddagger}\end{array}$ & $\begin{array}{l}\text { Babesia spp. in } \\
\text { the tick } \text { tis }^{\S}\end{array}$ & $\begin{array}{l}\text { Tick feeding } \\
\text { duration }(\mathrm{h})\end{array}$ & $\begin{array}{l}\text { Developmental } \\
\text { stage of } \\
\text { the tick }\end{array}$ \\
\hline Afa 89 & $1: 128$ & 1:128 & B. venatorum & 25 & $\mathrm{~N}$ \\
\hline Vofa 15 & $1: 256$ & $1: 256$ & B. microti & 35 & A \\
\hline Vifa 25 & $1: 64$ & 1:64 & B. microti & $<24$ & A \\
\hline tKafa 6 & $1: 256$ & 1:256 & Neg. & $<24$ & $\mathrm{~N}$ \\
\hline †Kafa 52 & $1: 64$ & 1:64 & Neg. & 25 & $\mathrm{~N}$ \\
\hline †Kfa 11 & $1: 128$ & $1: 64$ & Neg. & ND爪 & $\mathrm{N}$ \\
\hline tKfa 13 & $1: 64$ & $1: 64$ & Neg. & $<24$ & A \\
\hline
\end{tabular}

521

522 "Participant Id. code. Letters representing primary healthcare center where tick was collected followed by serial number.

523 tSample from control group

$524 \quad \neq 1^{\text {st }}$ sample collected at inclusion, $2^{\text {nd }}$ sample after three months

$525 \S$ Babesia spp. found in the tick collected at inclusion

$526 \pi N D=$ not determined due to deformed tick, making scutal and coxal indices impossible to determine

$527 \quad$ A $=$ Adult female, $N=$ nymph

528 
531 Figure 1. A. Map, showing the four regions (Northern Sweden, South Central Sweden,

532 Southernmost Sweden, Åland Islands) where the 34 primary health care centers (PHCs, black

533 dots) are located. B. Map showing PHCs where ticks positive for different Babesia species

capreoli (filled green circles). Numbers $(\mathrm{X} / \mathrm{Y})$ next to region showing number of positive

536 ticks in each region (X) with total number of ticks collected (Y). Maps modified from

537 Wilhelmsson et al. 2013b.

538 Figure 2. Flow-chart showing the study design and methods. Green for information regarding 539 ticks, red for blood samples and blue for questionnaires.

540 *Excluded because no samples were available, they had been used for previous analyses.

$541+$ Excluded since sera were not available, it had been used for previous analyses.

$542 \mp$ Denoted as the negative control group.

543

544 Appendix. 65 ticks positive for Babesia in real-time PCR

\begin{tabular}{|c|c|c|c|c|c|c|}
\hline Region & $\begin{array}{l}\text { Id. } \\
\text { Number }\end{array}$ & $\begin{array}{l}\text { Developmental } \\
\text { stage of the } \\
\text { tick§ }\end{array}$ & $\begin{array}{l}\text { Feeding } \\
\text { time (h) }\end{array}$ & $\begin{array}{l}\text { Babesia spp. in } \\
\text { the tick }\end{array}$ & $\begin{array}{l}\text { Borrelia } \\
\text { spp. in the } \\
\text { tick }\end{array}$ & $\begin{array}{l}\text { Estimated } \\
\text { no. of } \\
\text { spirochetes }\end{array}$ \\
\hline \multirow{27}{*}{ Aland Islands } & Afa 22 & $A$ & $<24$ & B. microti & B. afzelii & $3.3 \times 10^{2}$ \\
\hline & Afa 89 & $\mathrm{~N}$ & 25 & B. venatorum & B. afzelii & $3.1 \times 10^{3}$ \\
\hline & $\begin{array}{l}\text { Afa } \\
115 B^{*}\end{array}$ & $\mathrm{~N}$ & $<24$ & B. venatorum & & \\
\hline & Afa 132B & $\mathrm{N}$ & 46 & B. venatorum & $\mathrm{ND}^{\ddagger}$ & 1 \\
\hline & Afa $132 \mathrm{C}$ & $\mathrm{N}$ & $<24$ & B. microti & & \\
\hline & Afa 132D & A & 30 & B. venatorum & & \\
\hline & Afa 144 & $\mathrm{~N}$ & 50 & B. venatorum & & \\
\hline & Afa 156A & $\mathrm{A}$ (male) & $-\dagger$ & B. venatorum & & \\
\hline & Afa 178 & $\mathrm{~N}$ & 42 & B. venatorum & & \\
\hline & Afa 185 & A & - & B. microti & & \\
\hline & Afa 190 & $\mathrm{~N}$ & $<24$ & B. venatorum & B. afzelii & $2.3 \times 10^{4}$ \\
\hline & Afa 217 & A & $<24$ & B. microti & B. afzelii & $1.6 \times 10^{4}$ \\
\hline & Afa 237 & A & 34 & B. venatorum & & \\
\hline & Afa 338 & $A$ & $<24$ & B. microti & & \\
\hline & Afa 350 & $\mathrm{~N}$ & $<24$ & B. microti & B. afzelii & $1.1 \times 10^{4}$ \\
\hline & Afa 380 & $\mathrm{~N}$ & 51 & B. capreoli & & \\
\hline & Afa 381 & $\mathrm{~N}$ & 30 & B. microti & & \\
\hline & Afa 412 & $\mathrm{~N}$ & 45 & B. venatorum & & \\
\hline & Afa 465 & $\mathrm{~N}$ & $<24$ & B. venatorum & & \\
\hline & Afa 466 & $\mathrm{~N}$ & 42 & B. venatorum & B. afzelii & $6.7 \times 10^{4}$ \\
\hline & Afa 476 & $\mathrm{~N}$ & $<24$ & B. microti & B. afzelii & $5.3 \times 10^{4}$ \\
\hline & Afa 498D & $\mathrm{N}$ & $<24$ & B. venatorum & & \\
\hline & Afa 499 & $\mathrm{~N}$ & $<24$ & B. venatorum & & \\
\hline & Afa 518A & $\mathrm{N}$ & $<24$ & B. microti & & \\
\hline & Afa 537 & $\mathrm{~N}$ & $<24$ & B. venatorum & & \\
\hline & Afa 560 & $\mathrm{~N}$ & $<24$ & B. microti & & \\
\hline & Afa $615 B$ & $\mathrm{~N}$ & 33 & B. microti & $\begin{array}{l}B . \\
\text { valaisiana }\end{array}$ & 3 \\
\hline
\end{tabular}




\begin{tabular}{|c|c|c|c|c|c|c|}
\hline \multirow[t]{21}{*}{$\begin{array}{l}\text { Southcentral } \\
\text { Sweden }\end{array}$} & Bafa 6 & $A$ & $<24$ & B. microti & B. afzelii & $3.4 \times 10^{2}$ \\
\hline & Bafa 73A & $A$ & $<24$ & B. microti & & \\
\hline & Bafa 86 & A & $<24$ & B. capreoli & $\begin{array}{l}\text { B. } \\
\text { burgdorferi } \\
\text { sensu } \\
\text { stricto }\end{array}$ & $3.1 \times 10^{4}$ \\
\hline & Ekfa 84 & $A$ & - & B. microti & B. afzelii & $2.7 \times 10^{4}$ \\
\hline & Grfa 28 & $\mathrm{~N}$ & 56 & B. microti & B. garinii & $1.3 \times 10^{3}$ \\
\hline & Hafa 8 & $\mathrm{~N}$ & $<24$ & B. venatorum & & \\
\hline & Hafa 16 & $\mathrm{~N}$ & 25 & B. microti & B. afzelii & $3.1 \times 10^{4}$ \\
\hline & Hafa 44B & $A$ & $<24$ & B. venatorum & $\begin{array}{l}B . \\
\text { miyamotoi }\end{array}$ & $1.9 \times 10^{6}$ \\
\hline & Hafa 115 & $A$ & 61 & B. venatorum & B. afzelii & $1.7 \times 10^{1}$ \\
\hline & Jofa 7 & $\mathrm{~N}$ & 47 & B. microti & B. afzelii & $6.3 \times 10^{2}$ \\
\hline & Lidfa 14 & $\mathrm{~N}$ & 55 & B. venatorum & B. garinii & $1.4 \times 10^{3}$ \\
\hline & Lidfa 30 & A & $<24$ & B. microti & ND & $1.1 \times 10^{2}$ \\
\hline & Lidfa 39A & $\mathrm{L}$ & - & B. capreoli & & \\
\hline & Lidfa 39B & $\mathrm{N}$ & 52 & B. capreoli & & \\
\hline & Lidfa 46 & $\mathrm{~N}$ & 26 & B. venatorum & & \\
\hline & Lidfa 92B & $\mathrm{N}$ & $<24$ & B. microti & B. afzelii & $3.9 \times 10^{4}$ \\
\hline & Mekfa 16 & $A$ & - & B. venatorum & & \\
\hline & Sofa 76 & A & 166 & B. microti & ND & $1.1 \times 10^{2}$ \\
\hline & Vvfa 66 & $A$ & - & B. microti & & \\
\hline & Vifa 20 & $\mathrm{~N}$ & 70 & B. microti & & \\
\hline & Vifa 25 & A & $<24$ & B. microti & B. afzelii & $1.9 \times 10^{5}$ \\
\hline \multirow{17}{*}{$\begin{array}{l}\text { Southernmost } \\
\text { Sweden }\end{array}$} & Blefa 13 & $\mathrm{~N}$ & $<24$ & B. microti & B. afzelii & $7.9 \times 10^{3}$ \\
\hline & Blefa 19 & $\mathrm{~N}$ & 37 & B. microti & & \\
\hline & $\begin{array}{l}\text { Blefa } \\
38 \mathrm{~B}\end{array}$ & $\mathrm{~N}$ & $<24$ & B. microti & B. afzelii & $8.8 \times 10^{3}$ \\
\hline & $\begin{array}{l}\text { Blefa } \\
38 D\end{array}$ & $\mathrm{~N}$ & $<24$ & B. venatorum & B. afzelii & $9.5 \times 10^{2}$ \\
\hline & Kafa 7 & $\mathrm{~N}$ & 57 & B. venatorum & & \\
\hline & Kafa 34 & $\mathrm{~N}$ & 59 & B. venatorum & & \\
\hline & Kafa 36 & $\mathrm{~N}$ & $<24$ & B. microti & B. afzelii & $3.5 \times 10^{3}$ \\
\hline & Kafa 75 & $\mathrm{~N}$ & 49 & B. microti & & \\
\hline & Kafa 84A & $\mathrm{N}$ & 60 & B. microti & B. afzelii & $7.0 \times 10^{1}$ \\
\hline & $\begin{array}{l}\text { Kafa } \\
100 A\end{array}$ & $\mathrm{~N}$ & 25 & B. microti & B. afzelii & $1.8 \times 10^{4}$ \\
\hline & Kfa 9 & $\mathrm{~N}$ & $<24$ & B. venatorum & & \\
\hline & Kfa 18 & $\mathrm{~N}$ & - & B. venatorum & & \\
\hline & Kfa 25 & $\mathrm{~N}$ & 37 & B. capreoli & & \\
\hline & Lafa 13 & $A$ & 51 & B. venatorum & & \\
\hline & Ofa $15 \mathrm{C}$ & $\mathrm{N}$ & 35 & B. microti & B. afzelii & $1.4 \times 10^{4}$ \\
\hline & Vofa 15 & $A$ & 35 & B. microti & & \\
\hline & Ysfa 9 & A & 38 & B. microti & B. afzelii & $1.5 \times 10^{1}$ \\
\hline
\end{tabular}

545 "Letter after Id. Code for participants who turned in more than one tick to the PHC, the first tick XXfaA, the second XXfaB etc $546 \quad$ TFeeding time could not be determined $547 \quad \mp N D=$ Species could not be determined 548 \$ $=$ Adult female, $N=$ nymph 


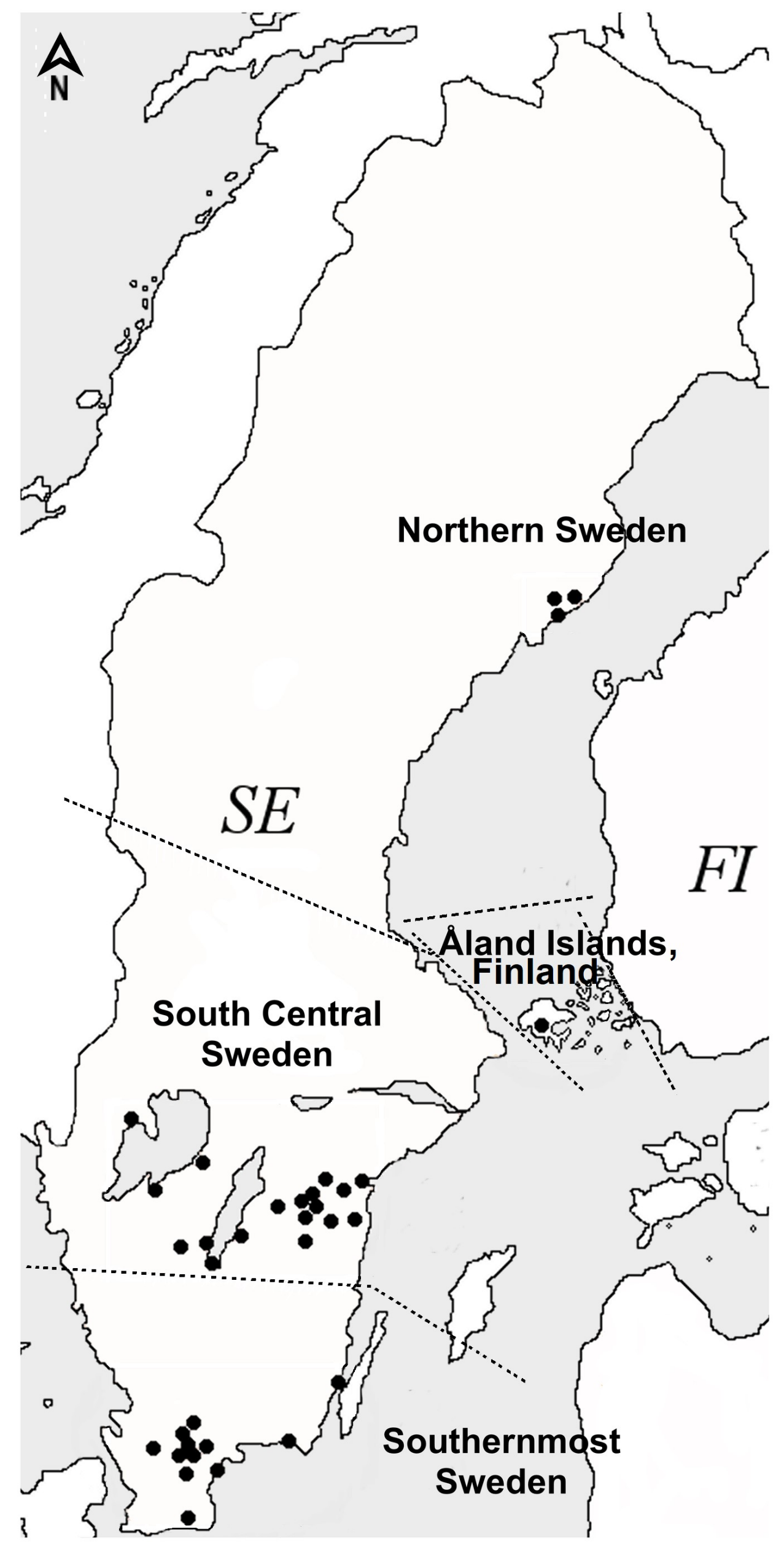




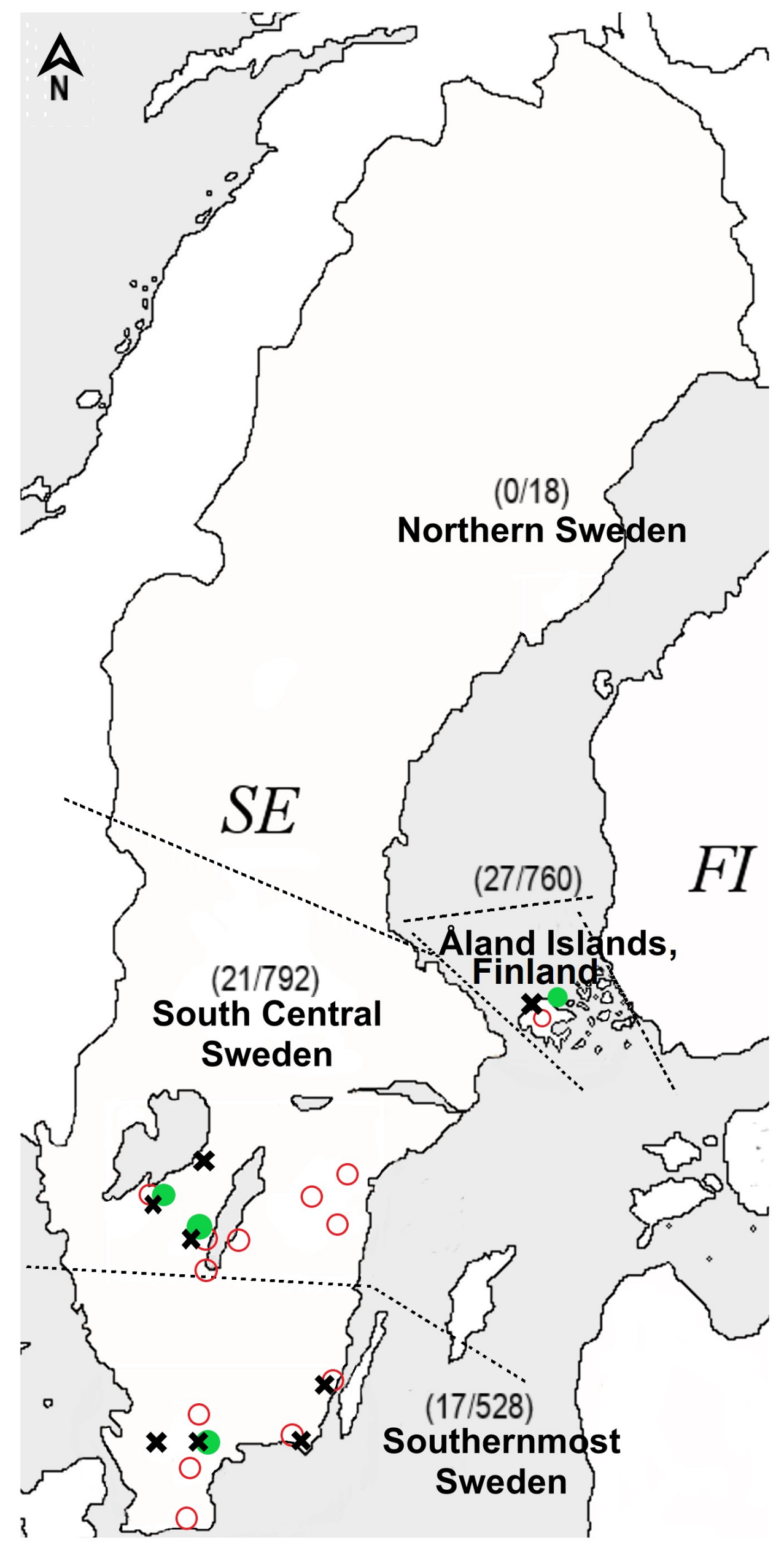




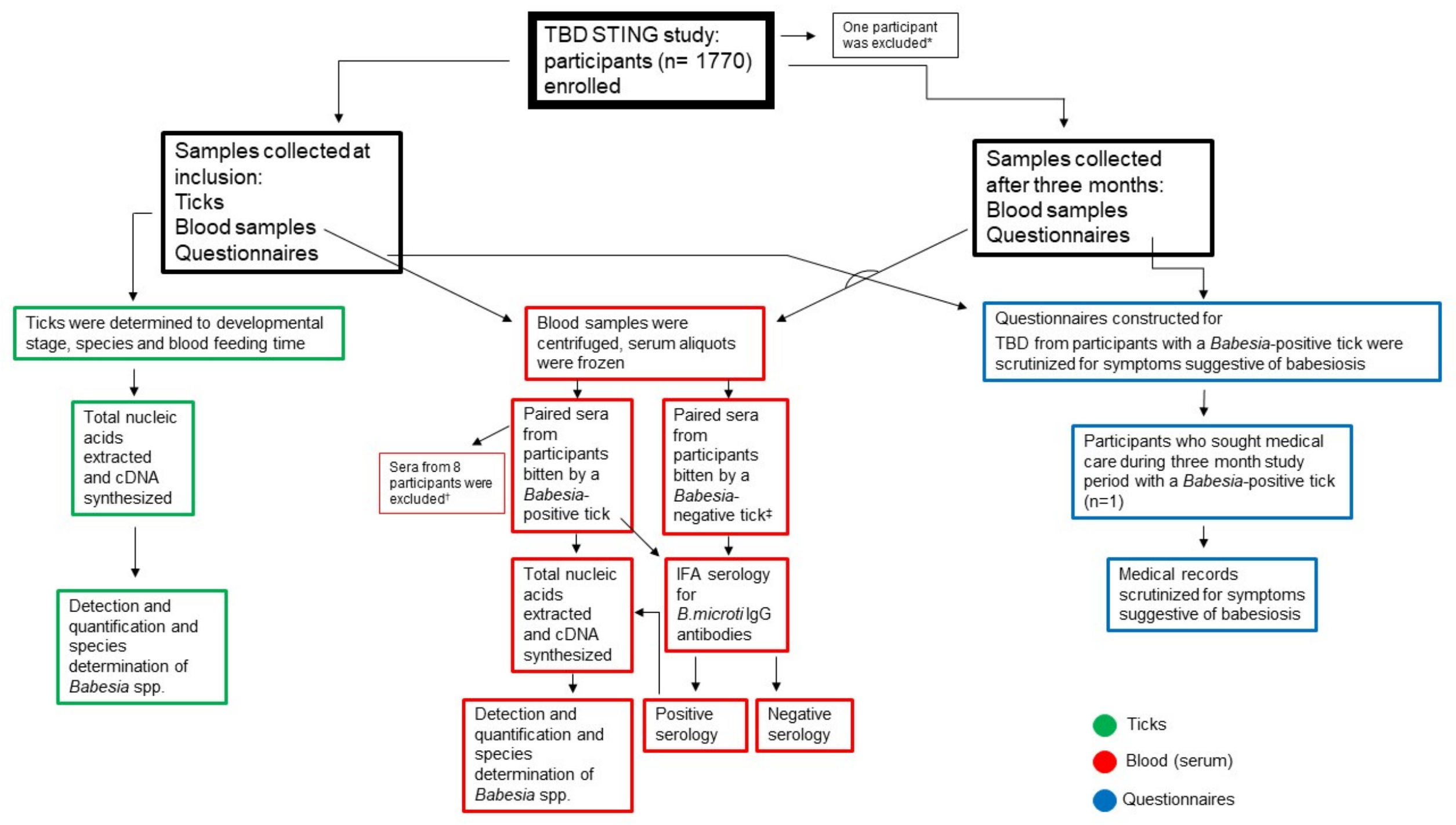




\section{CREDIT AUTHOR STATEMENT}

Wilhelmsson, Peter:

Conceptualization

Formal Analysis

Investigation

Writing - Review \& Editing

Supervision

Lövmar, Matilda:

Investigation

Data Curation

Writing - Original Draft

Writing - Review \& Editing

Visualization

Krogfelt, Karen Angeliki:

Conceptualization

Project Administration

Writing - Review \& Editing

Nielsen, Henrik Vedel:

Investigation

Resources

Writing - Review \& Editing

Forsberg, Pia:

Conceptualization

Resources

Writing - Review \& Editing

Supervision

Project Administration

Funding Acquisition

Lindgren, Per-Eric:

Conceptualization

Writing - Review \& Editing

Supervision 
Project Administration

Funding Acquisition 